Papers and Proceedings of the Royal Society of Tasmania, Volume $10 \%$.

\title{
THE EXTENT OF UPPER MESOZOIC IGNEOUS ACTIVITY IN RELATION TO LAMPROPHYRIC
}

\author{
INTRUSIONS IN TASMANIA \\ by li. i. Sutherland (1) and li.r. Corbett \\ (1) Australian Muscun, bydney, fomerly Tasmanian Muscum, Hobate and \\ (2) formerly B.H.P. Co. i,d., Hobart and bepartment of Minos, itobart. \\ (with one tablo and four figures)
}

\section{ABSTRACT}

Recent mapping and petrological work, associated with some clating, demonstrates a wider range of Upper Mesozolc intrusives and post-Lower bovonian lamprophyres than previously recognized in Tasmania. 'lheir distribution suggests significant igneous activity across the state, iut knowledge of its full extent is dependant on detailed separation of some lamprophyres from those of older igneous episodes.

Al1 the rocks, so far assigned to the Upper Mesozoic magmatic episode in Tasmania, are potassic in nature with shoshonitic affinities. They form the southern extension of similar magmatism around Bass Strait and in castern Australia.

\section{INTRODUCTION}

In the early exploration of Tasmania, Péron in the 1802-1803 French Lxpedition collected a hybrid (?) rock from Cygnet (von Buch 1814) and Strzelecki (1845 p. 99) listed a petrosilex porphyry from Cape Portland. This paper illustrates a link between the rocks of these two early finds and places them in a distinctive, but previously incompletely elaborated episode in Tasmania's geological history.

Upper Mesozo: events have only minor record in the Tasmanian literature and the break between the dequitous injection of Mid-Jurassic tholeitic magna and the latest Mesozoic/early Palacocene epeirogeny has been largely regarded as a prolonged period of terrestrial denudation (Spry and Banks 1962; Jonnings, Noldart and Williams 1967). Some ferruginous and bauxitic deposits may belong here (Hi1s and Carey 1949; Green 1959), but the first proven rocks of this age were established with the isotopic dating of mid-Cretaceous intrusives at cygnet (Evernden and Richards 1962). This established igneous activity during this period and its extent is pertinent to this enguiry.

Recent mapping by geologists of the Tamanian Mines Department, Tasmanian Museum, Geology Department - Univorsity of Tasmania, hydro-Electric Comission, Broken Hill Pty. Co. Ltd. and Mt. iyell Co. lty. lt. now demonstrates further rocks that belong or may belong to Upper Mesozoic magmatism. The rocks beiong to three main groups:

(1) Cygnet suite, southem Tasmania; in part confimed as Mid-Cretaccous (McDougall and Leggo 1965) and forming potassic alkaline intrusives related in space and petrology.

(2) Cape Portland suite, northeastem Tasmania; provisionally dated as Upper Mesozoic and forming potassic 'appinitic' intrusives and lavas related in space and petrology (Jennings and Sutherland 1969).

(3) West Coast lamprophyres; post-Lower Devonian intrusjons, largely biotite lamprophyres and including a King Island dyke dated at $137 \mathrm{m.y}$. NoDougall and Leggo 1965). 


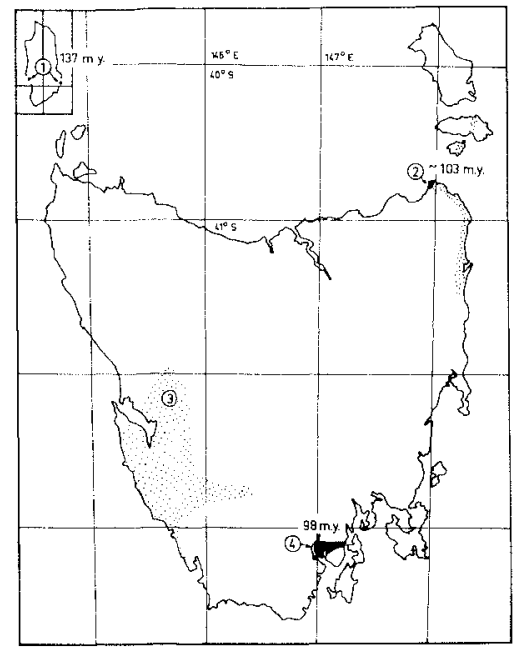

FIG. 1 - Areas of dated Upper Mesozoic igneous rocks and West Coast lamprophyres in Tasmania. 1-King Island minettes, 2-Cape Portland complex, 3-West Coast lamprophyres, 4-CygnetD'Entrecasteaux Channe1 intrusives.
A11 these groups tend to have common chemical and petrological characters, particularly their potassic nature, and where dated have comparable Upper Mesozoic ages. In addition, if broad contemporaneity is assumed for these groups, they appear to fall into a differentiation series (Sutherland 1973a) and may therefore be consanguineous. Thus, it is reasonable to suggest that all or most of the rocks of group (3) may be Upper Mesozoic, an age not inconsistent with the field evidence. If the above arguments apply, then Upper Mesozoic igneous activity in Tasmania was more widespread than previously considered. Description of the three groups and evidence for their age and extent forms the main body of this paper.

\section{SOUTHERN TASMANIA}

\section{Huon-Cygnet-Oyster Cove Area}

The alkaline intermediate intrusives in this district (fig. 1) attracted considerable attention after their record on the Johnston (1888) map and early description by Twelvetrees and Petterd (1898,1899-1900). Most of the subsequent work is listed in the later detailed descriptions of the complex (Edwards 1947; Leaman and Naqvi 1967; Tasmanian Department of Mines 1970) and its palaeomagnetic and isotopic age measurement (Evernden and Richards 1962; Robertson and Hastie, 1962; McDougal1 and Leggo 1965). These data suggest Mid-Cretaceous emplacement $(98+3 \mathrm{m.y}$.$) of syenitic (monzonitic)$ magma into domed Permian strata, forming intrusive sheets of porphyritic banatite-akerite. The magma apparently arose as a skin effect along a Jurassic dolerite intrusion producing a zone of contact metamorphic and hybrid rocks near lft. Mary. An accompanying swarm of syenitic and unsaturated alkaline dykes (porphyritic banatite, orthoclasite, aplite, pegmatite, tinguaite and hauyne-garnet sanidine porphyry) show trends partly reflecting a regional N.N.E.-S.S.W. tensional control (fig. 2). The event was associated with minor gold and sulphide mineralization (Smith 1899; Twelvetrees 1902, 1908; Kemezys 1971).

\section{D'Entrecasteaux Channel}

Although extension of the Cygnet intrusives to D'Entrecasteaux Channel was recognised (Hogg 1901-1902; Skeats 1917; Hills et al.1922; Edwards 1947) these were not mapped in detail and are much more extensive than depicted. Recent close mapping oi the channel shore (fig. 3) has revealed numerous intrusions in the coastal outcrops from Oyster Cove to Peppermint Bay but they prove difficult to trace inland under the soil cover.

The intrusions form a series of sills and dykes in Permian sediments and Jurassic dolerite. The main exposures are one side of a wide irregular dyke $(200 \mathrm{~m}$ across) in Permian rocks between Peppermint and Little Peppermint Bays, an eroded transgressive sill-1ike extension of this body between Little Peppermint and Perch Bays and an extensive E.N.E. - W.S.W. trending dyke complex invading dolerite and Permian west of Kettering. One of the major bodies of the Kettering complex is exposed for $200 \mathrm{~m}$ along the road $0.3 \mathrm{~km}$ west of the ferry turn-off, where it has intruded along a dolerite-Permian contact and mineralized the strongly-baked permian sediments. North of this, other dykes of the complex intrude through to the other side of the dolerite body and into uplifted basal permian (?) tillite that shows contact metamorphism into hornfels with calcsilicate phases and reaction coronas around pebbles. 

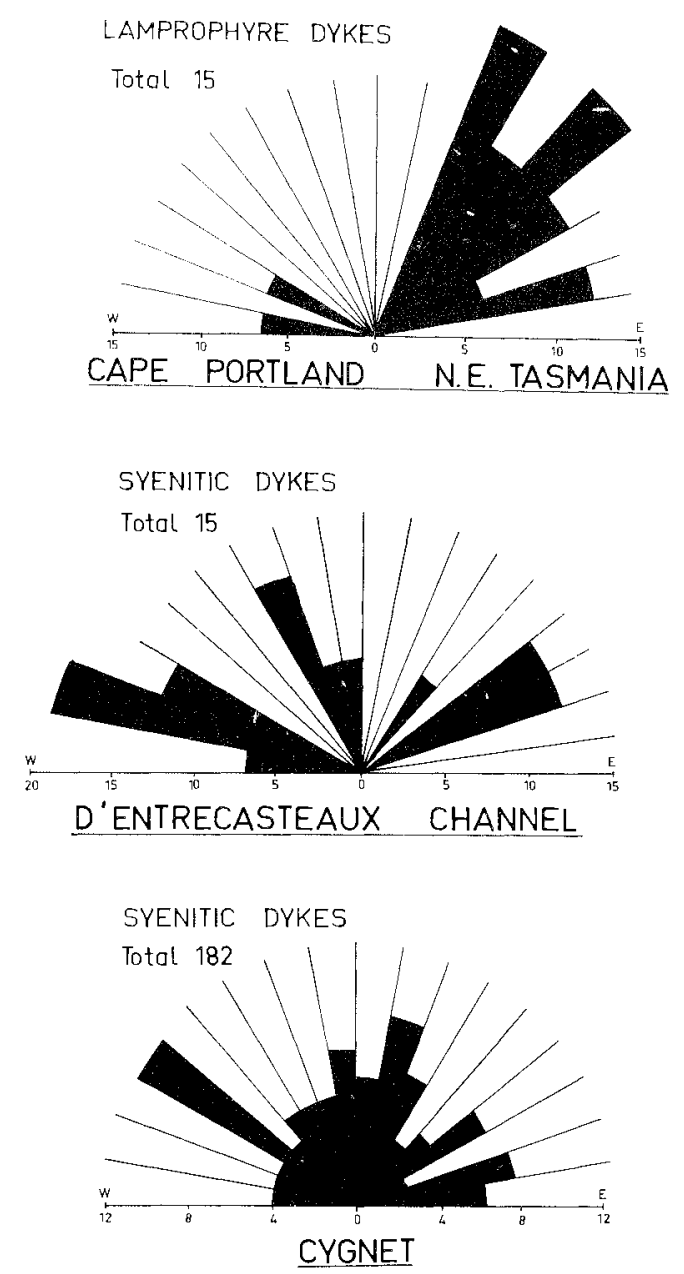

FIG. 2 - Rose diagrams showing comparative dyke trends from dated Upper Mesozoic intrusive complexes. Data on the Cygnet dykes is taken from Leaman and Naqvi (1967).

In the coastal exposures, minor steep and inclined dykes (up to $25 \mathrm{~m}$ wide) intrude, (a) basal permian (?) tillite downfaulted in Little Peppemint Bay (dyke trends $152-160^{\circ}$ ), (b) Permian beds upthrown in Peppermint Bay (trends 93-148 ) and Little Oyster Cove (trends $77-88^{\circ}$ ) and (c) dolerite around Little oyster Cove (trends $\left.34-108^{\circ}\right)$. These dykes show some tendency to an arrangement radial from the complex south-west of Kettering, but W.i.i..-E.S.E. trends dominate in similar fashion to Cygnet trends (fig. 2), al though the major structures trend E.iN.E.-W.S.W. in contrast. Several associated small sills (up to $10 \mathrm{~m}$ thick) intrude the tilted permian strata with undulose contacts and dip up to $50^{\circ} \mathrm{E}$. Two sills occur in the succession south of Oyster Cove and sil1s fed from dykes are seen along Peppermint and Litt1e Peppermint Bays and at the dolerite-Permian contact on the point east of Kettering. 


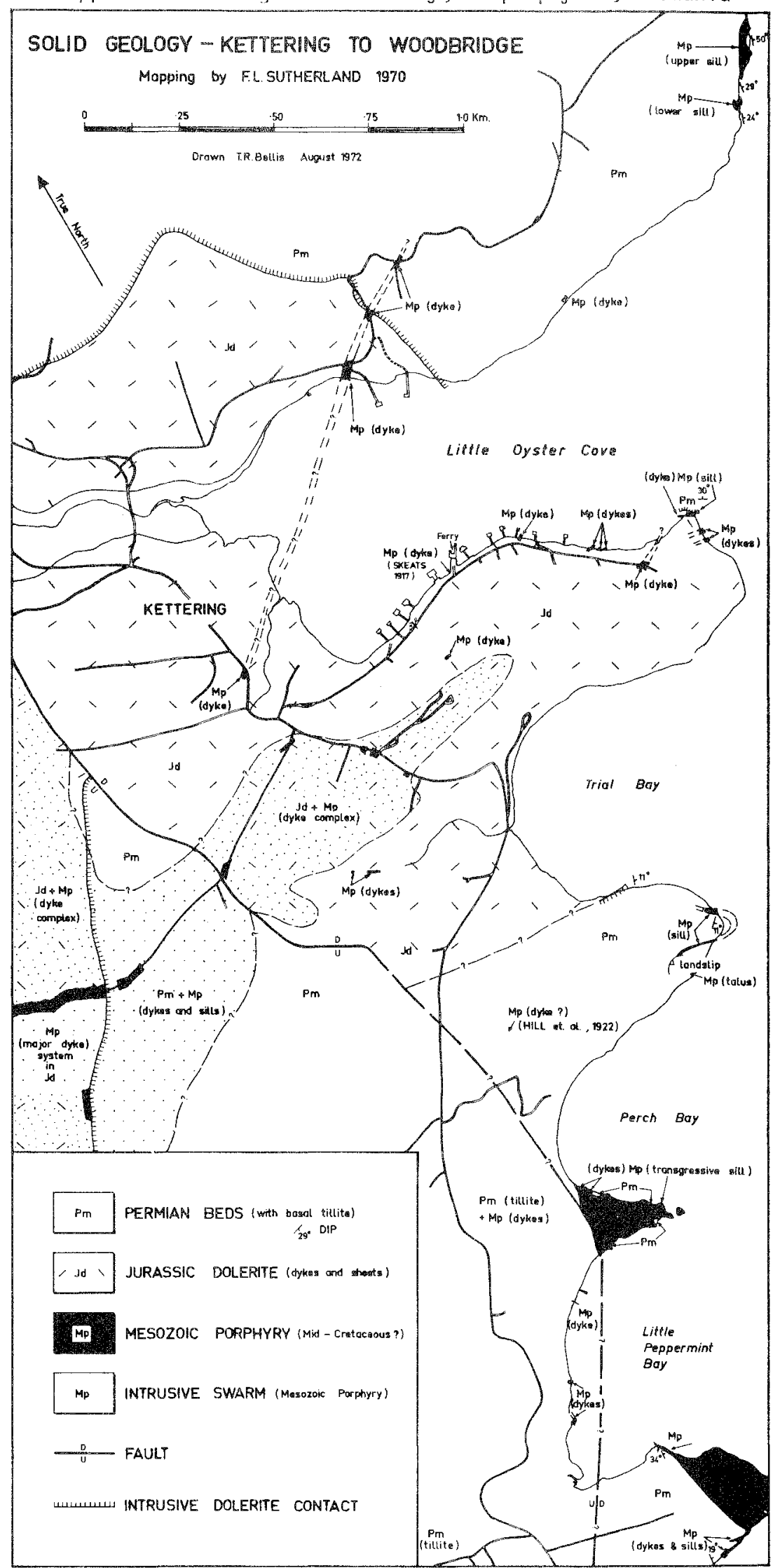


The major bodies are emplaced near large faults or along intrusive dolerite contacts. The overall pattern of the complex suggosts an original network of steep dykes connected with near-horizontal sills, with some of the major dykes splitting and branching outwards into thimer bodies at higher levels. This Cretaccous complex was then tilted and faulted during the late Mcsozoic-Palacocene epejrogenic movements of Tasmania. The intrusions are massive with blocky to rhombic and, in some cases, course platy jointing, wich represents both Cretaceous thermal cooling and the later epeirogenic joint patterns.

Marginal chiling and baking and alteration of tho host rocks is generally slight associated with smaller intrusions, effects rarely extcnding more than $2 \mathrm{~m}$ from contacts. Altoration of colerite is evident ncar contacts with the main dyke swarms, with replacenent of pyroxenes by hormblende and foathery actinolite. 'l'he Permian strata show isolated zoncs of strong silicification at oyster Cove and Little Peppermint Bay (Sutherland 1971) and are commonly dappled with green secondary mineral staining; these features may relate to the nearby syenitic intrusions.

The D'Entrecasteaux Channel intrusives are composed of 'syenitic' porphyry, sometimes showing fluidal arrangement of phenocrysts (Skeats 1917; Edwards 1947). In thin sections all the rocks are porphyritic banatite. 'They usually contain abundant oscillatorilly-zoned tablets of andesine $\left(A b_{55-65}\right)$ and rarer sanidine $\left(\mathrm{Or}_{33} \mathrm{Ab}_{45} \mathrm{Ar}_{22}\right)$, up to $3 \mathrm{~cm}$ across, in association with smaller zoned prisms of greenbrown aluminous hornblende (Analysis 1, Table 6, Ldwards 1947) that may pass marginally into greenish blue alkali amphitole. These, with rarer microphenocrysts of ferrian augite, sphene and apatite, commonly grade into an orthophyric groundmass with orthoclase, interstitial quartz and dispersed magnetite. Sporadic sulphides may be present and include euhedral pyrite, iyrrhotite-chalcopyrite intergrowths, secondary pyrite and minor arsenopyrite. In a few dykes, epidote is conspicuous amongst the phenocrystic minerals, perhaps as a pseudomorphic phase.

The rock in the large dyke and sill-1ike extension at Little peppermint Bay and in the upper sill south of Oyster Cove is notable for numerous fine to mediumgrained, cognate, nafic aggregates up to $10 \mathrm{~cm}$ across. Some of these may represent localized accumulations of hornblende, augite and sphene in the felsic groundmass, but others clearly represent earlier crystallate brought up with the magma. The most mafic types are the coarser hornblendites composed almost entirely of cumulative green-brown hormblende crystals up to $15 \mathrm{~mm}$ across, with minor sphene and apatite. Some inclusions are altered micro-quartz syenite containing considerable epidote. ihus, there is suggestion of intrusion of more xenolithic magma along an eastern line from Little Peppermint Bay, separate from intrusives derived from the complex west of Kettering.

Accidental xenoliths of host rocks within the intrusives include baked Pormian sediments in fragments up to $30 \mathrm{~cm}$ and as isolated blocks up to $30 \mathrm{~m}$ across. Exotic rock fragments appear in the dykes intruding the tillite at Littje peppermint Bay (Hogg 1901-1902).

Overall, syenitic intrusions of the cygnet type are now known to extend from, Woodbridge-Oyster Cove towards Dover, implying a minimum area of at least $350 \mathrm{Km}^{2}$ for the activity. The syenites intrude up to the top of the permian marine beds, but not into the overlying massive freshwater Triassic sandstones even when immediately adjacent in outcrop (Leaman and Naqvi 1967). Thus the actual area of intrusion may be considerably greater than exposed.

\section{.ORTH-EASTERN TASMANIA}

A potassic dioritic (porphyrite) complex, associated with spessartitic, kersant-

FIG. 3 - Solid Geology of the Kettering Woodbridge area, L'Lntrecasteaux Channel, showing distribution and forms of the Upper Mesozoic intrusives (see opposite page). 
itic and rare vogesitic dykes and 'trachyandesitic' lavas, is centred near Cape Portland (fig. 1); stratigraphic evidence suggests that it is probably Upper Jurassic/Lower Cretaceous in age (Jennings and Sutherland 1969). 1:ecent measurements on a dyke (locality 22 ) gave magnetization directions of Decl. $354^{\circ}$ and Incl. $-84^{\circ}$ with nomal polarity (Wyatt 1971), comparable with directions detemined for the Cygnet complex (Robertson and Hastie 1962). Lecent isotopic dating of some of the rocks (C. Brooks G D.J. Jennings, Tasm. iines Dept., rept. in prep.) gave minimum ages ranging from $91 \pm 1 \mathrm{~m} \cdot \mathrm{y} \cdot(\mathrm{K} / \mathrm{Ar})$ to $103+23 \mathrm{~m} \cdot \mathrm{y} \cdot(\mathrm{Rb} / \mathrm{Sr})$, supporting a Lower to Mid-Cretaceous age for emplacement.

The dykes show approximately radial distribution around the central complex, but are dominated by NE-SW trends ( $\mathrm{fig}$. 2). This is an unusual dominant post-PaIaeozoic intrusive trend for Tasmania and contrasts with the main trend of the Cygnet suite, suggesting emplacement of the Cretaceous magmas under locally different tensional and/or basement structural controls. Regional basenent trends are generally north westerly to northerly in N.E. Tasmania swinging north-easterly in eastern Bass Strait (Sutherland 1973b), wut the precise relationship of the Cape Portland complex to these trends is obscured by Jurassic dolerite cover.

Chenical analyses of the Cape Portland suite (sumary, Table 1) indicate parent magma compositionally intemediate between the average diorite and average monzonite of Nockolds (1954) and transitional towards shoshonitic associations (Sutherland 1973a). The dyke compositions match fairly well with corresponding average kersantite and spessartite compositions of Métais and Chayes (1963), except for high Fe/ $\mathrm{Mg}$ ratios.

Similar rocks to the Cape Portland intrusives have been mapped more recently, cutting granite basement south and north of the complex (D.J. Jenning and J.D. Cocker, pers. comm.). They include dykes $4 \mathrm{~km}$ north-west of Mussel Roe Bay (E-W trending hornblende-augite spessartite with cognate mafic inclusions), $8 \mathrm{~km}$ north-west of Eddystone point (hornblende-plagioclase spessartites) and 1 km west of Puncheon Point, Cape Barren Island (E-W trending altered porphyritic banatite). Further afield, detailed mapping of the St. ielens granodiorite intrusives has revealed at least nine younger dykes up to $6 \mathrm{~m}$ wide and at least $100 \mathrm{~m}$ long (Cocker 1971), which in thin sections compare closely with Cape Portland porphyrites and spessartites and chemically show similar high $\mathrm{K}_{2} \mathrm{O} / \mathrm{Na}_{2} \mathrm{O}$ ratios. Intermediate hornblendic rocks in small intrusions occur elsewhere in ${ }^{2} \mathrm{~N}$. E. Tasmania and include diorite porphyrite at Scamander Tier (Walker 1957), hornblende picrite at Scamander (Longman 1961), hornblende lamprophyre at Canden (Everard, in Longman 1966) as well as hornblende monzonite at Priory, hornblende dolerite at Blue Tier and altered micro-porphyrite ex situ at Kangaroo Bay, Clark Island, (J.L. Cocker, D.J. Jennings and D.I. Groves, pers. comm.). Some of the above rocks may be related to the Mid-Upper Palaeozoic granites, but an Upper Mesozoic age cannot be discounted on present evidence.

\section{WESTERN TASMANIA}

Lamprophyres have been noted fron widely scattered localities in Western Tasmania, but lie within two separate areas, King Island and a West Coast belt that extends from north of Queenstown to south of Low Rocky Point and across to the Florentine Valley (figs. 1 and 4).

On King Island, Waterhouse (1916) reported lamprophyric dykes that in places traversed the Newer granite of the Island and he also referred to various dykes of undetemined hornblendic rocks. An olivine minette dyke intrudes Cambrian basic volcanics on the east coast north of Grassy, on a trend related to post-volcanic faults striking about 290-300 (Scott 1951; Solomon 1964; J.D. Cocker pers. comm.). In thin sections this appears identical to and may be the same biotite lamprophyre dated by McDouga1l and Leggo (1965). The rock contains large orthopyroxene and clinopyroxene crystals with resorbed margins that are probably accidental xenocrysts from the basic host rocks. A similar minette dyke of approximately $E-W$ trend intrudes 


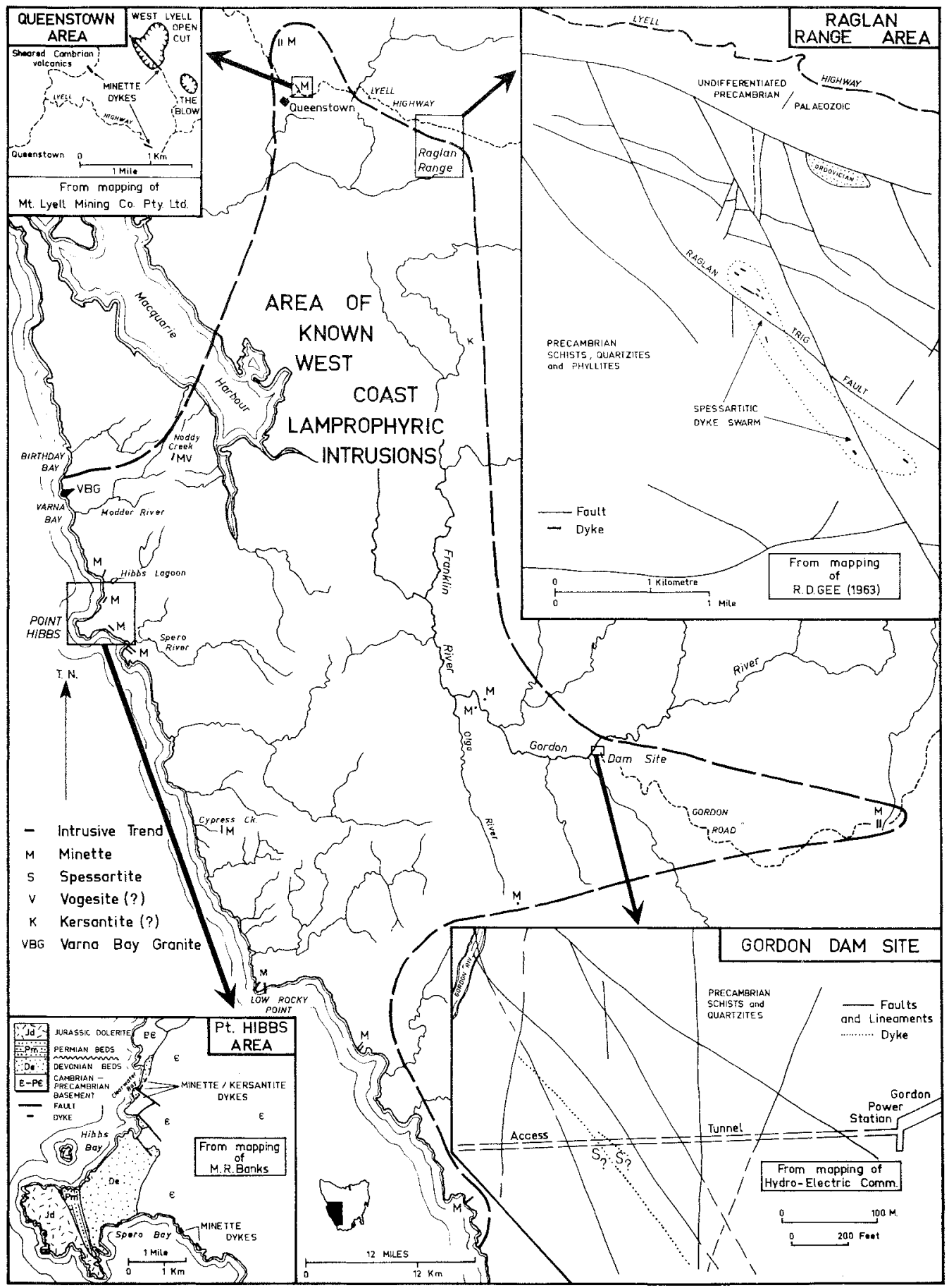

FIG. 4 - Map showing localities, trends, structural relationships and petrology of the West Coast lamprophyres. 
Precamberin schists on the west coast of the Island about $0.6 \mathrm{~km}$ south of Currie (J.D. Cocker pers. comm.), but in thin sections contains accidenta1, margina11yresorbec quartz instead of nafic inclusions. Thus, king Island lamprophyres include potassic types and some at least appear to post-date the Newer granite $(345 \mathrm{~m} . \mathrm{y}$.$) ,$ possibly being as young as Mid-Mesozoic $(137 \mathrm{~m} . \%$.$) , on dating by McDougall and$ Leggo (1965).

'The hest Coast lamprophyres all consist of narrow tubular bodies, generally 0.3 - $2 \mathrm{~m}$ wide, but up to $4.5 \mathrm{~m}$ on Raglan Range and $9 \mathrm{~m}$ at Gordon Dam. Many are concordant in well-bedded rocks and parallel the cleavage in the schistose volcanics, but some are fult controlled. At Qucenstown dykes are exposed for distances up to $420 \mathrm{~m}$ and if correlated can be traced over a kilometre both laterally and down in subsurface intersections in the workings. Elsewhere dykes can rarely be traced more than about ten metres, although many occur tens of kilometres from the nearest known granitic intrusion. Although some lamprophyres are weathered many are remarkably fresh. The degree of weathering and alteration may depend partly on the nature of the host rocks and it is notable that those close to granite rocks at Varna Bay show pronounced hydrothermal effects.

Field relationship of the West Coast lamprophyres are insufficiently precise for direct age comparison with king Island dykes and no isotopic dating is available. liowever, there are some petrographic similarities, as (olivine) augite minettes predominate, associated with rarer kersantitic and vogesitic types. The Raglan Range and Gordon Dam rocks, however, are mainly spessartites, with the latter perhaps grading towards vogesite.

\section{(Olivine) Augite Minettes}

These are fine-grained, massive micro-porphyritic rocks speckled with biotite. In thin sections they contain biotite, clinopyroxene and sometimes altered olivine, up to $4 \mathrm{~mm}$ across, grading into a K-feldspar, chlorite, quartz and carbonate groundmass, with iron ore and apatite. Iypical modes of rocks from Spero Bay are Or. 50\%, Biot. 17\%, upx. 13\%, Chl. $9 \%$, Qtz. 5\%, Garb. 4\%, Pyr.-Mag. 1\%, Ap. 1\% (relatively unaltered type) and $0 \mathrm{r}$. $56 \%$, Chl. 20\%, Biot. 12\%, Carb. 6\%, Qtz. 4\% (altered type). The groundmass is generally crystallized, iut an intrusion from Noddy Creek contains the phenocrysts in a glassy base. Chilled, altered contact minette from Spero Bay contains Or. $40 \%$, Biot. $35 \%$, Caxb. $12 \%$, Lh1. 10\%, Qtz. $3 \%$.

Quartzose xenoliths, up to $10 \mathrm{~cm}$ across, are common in the 'Spero Bay intrusions', but are probably not Precambrian quartzite inclusions as suggested by Taylor (1955). The inclusions are fine- to medium-grained, banded to granular rocks containing variable proportions of quartz, largely unstrained, but commonly elongate and with parallel orientation, in a mosaic intergrowth with sericitized $K$-feldspar and sodic plagioclase (cAb 95). Sone show textures, such as increasing coarseness towards the margins, that are suggestive of thermal recrystallization of quartzo-feldspathic rocks incorporated into the Iamprophyric magma, either from the Cambrian country rocks or from a parental acid intrusion. From Noddy Creek a garnetiferous siliceous inclusion is thought to represent metamorphosed Precambrian basement (C1ose 1972).

The biotite forms strongly coloured crystals $(\alpha$ straw white, $\beta=\gamma$ reddish brown) passing into unevenly bleached ragged flakes that may be marginally altered to chlorite. The cinopyroxene is idiomorphic to granular, colourless to pale green diopsidic augite and is sometimes rimed by late magmatic (?) chlorite. In the more altercd rocks it is replaced by chlorite, iron ore and quartz. olivine occurs in serpentinized or talcose forms, but in many rocks it is absent or obliterated by replacement with chlorite and quartz.

k-feldspar is the main groundmass constituent, mostly forming irregular and occasionally prismatic zoned crystals, and rarely fine feathery and partly radiating clustered laths. It is comonly cloudy, and twinning when present is generally simple and often indistinct. Zoned, cloudy sodic plagioclase ( $>$ Ab 65 ) forms pro- 
minent laths with the K-feldspar in some of the Spero Bay, Noddy Creek and Clearwater Bay lamprophyres, which grade towards kersantite. Quartz forms round to irregular grains or single crystals and may be thinly rimmed with chlorite. Interstitial chlorite (greenish, faintly pleochroic irregular patches and flakes) appears to have crystallized with acicular carbonate (probably primary) as well as ragged secondary carbonate. Scattered pyrite, chalcopyrite and magnetite grains, apatite needles, sphene and homblende form minor constituents. A few of the Spero Bay and Noddy Creek rocks contain some coarse aggregates of quartz or feldspar with coronas of clinopyroxene granules and/or biotite flakes associated with carbonate and chlorite. These may represent slight reaction with small xenolithic fragments.

Chemical analyses of the Queenstown minettes (Solonon 1964) show near-saturated rocks that either contain minor quartz or up to $8 \%$ olivine in the norm (Table 1 ). Compared with the average minette composition of Métais and Chayes (1963) these are types deficient in $\mathrm{SiO}_{2}, \mathrm{Al}_{2} \mathrm{O}_{3}, \mathrm{Na} \mathrm{O}_{2}$ and $\mathrm{K}_{2} \mathrm{O}$ but are particularly enriched in

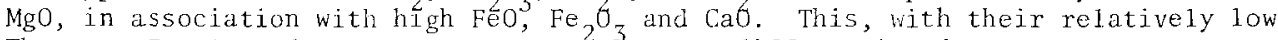
Thornton-Tuttle Index suggests comparatively undifferentiated types. In contrast the vogesite in an augite-poor minette from Noddy Creek, shows significantly higher $\mathrm{SiO}_{2}, \mathrm{Al}_{2} \mathrm{O}_{3}$ and $\mathrm{K}_{2} \mathrm{O}$ and lower MgO and $\mathrm{CaO}$, suggesting an extreme phase developed within a more highly differentiated minette (Close 1972).

\section{Hornblende-Augite-Spessartites}

Modal analyses and petrological descriptions of Raglan Range lamprophyres (Gee 1963) show spessartites containing variable proportions of amphibole (lamprobolite or hornblende) and augite phenocrysts. Chemically, they resemble the west coast minettes, except for lower $\mathrm{K}_{2} \mathrm{O}$ and greater $\mathrm{FeO} / \mathrm{Fe}{ }_{2} \mathrm{O}_{3}$ ratio, so that hornblende and plagioclase crystallized in place of biotite and potash feldspar to give more basic rocks with very low Thomton-Tuttle Index (Table 1). A further analysis of a Raglan Range lamprophyre (Spry and Banks 1962, analysis 72, p. 238) represents an acidic rock, apparently unrelated to the spessartites which may be an altered sodic fe1dspathic kersantite (?) from Surveyor Range (Spry 1957; F.L.S. microscopic obs.). The Gordon damsite rocks contain abundant glomeroporphyritic idiomorphic augite associated with reaction mantles and micro-phenocrysts of hornblende ( $\alpha$ pale brownish yellow, $\beta$ deep brown, $\gamma$ olive brown) in an altered groundmass 1 argely composed of sericitized sodic plagioclase, potash feldspar, chlorite and indeterminant clay.

\section{Varna Bay Granite Complex}

Some of the minettes may be related to this small hitherto undescribed body, as a dyke rock $90 \mathrm{~m}$ away and apparently derived from it, texturally resembles an altered variety of the lamprophyres.

The intrusion of mixed biotitic and feldspathic granite rocks is exposed for almost a kilometre along Varna Bay (fig. 4). It is enclosed in contorted quartzites, siltstones and minor dolomites and pinches out between faults about one $\mathrm{km}$ inland. Dolomites are unusually common near the contacts, particularly the southern contact.

North and south contacts show remarkable similarities - in each case the granite is sheathed by coarse indurated breccia with quartzite and phyllite fragments in a siliceous or partly calcareous matrix. The breccia generally has discordant relations with the surrounding sediments and may be somewhat baked, although there appears to have been no mineral growth.

Detailed field relationships are very complex and the area has had only brief study due to difficulty of access. Just south of the complex the sheathing breccia is deformed upwards around a circular body of white carbonate (about $7 \mathrm{~m}$ across). In composition, texture and mode of "intrusion" this body resembles and needs close evaluation as a carbonatite, particularly as such rocks can be associated with olivine-bearing lamprophyres and strongly potassic rocks of the types found in the general area (Joplin 1971). 
TABLE $1 \mathrm{~A}$

SUMMARY OF CHEMICAL ANALYSES, UPPER MESOZOIC INTRUSIVES AND POST-LOWER DEVONIAN (?) LAMPROPHYRES

Suite Cape Portland Appinitic Complex, ijykes and Lavas (Jemnings \& Suther1and

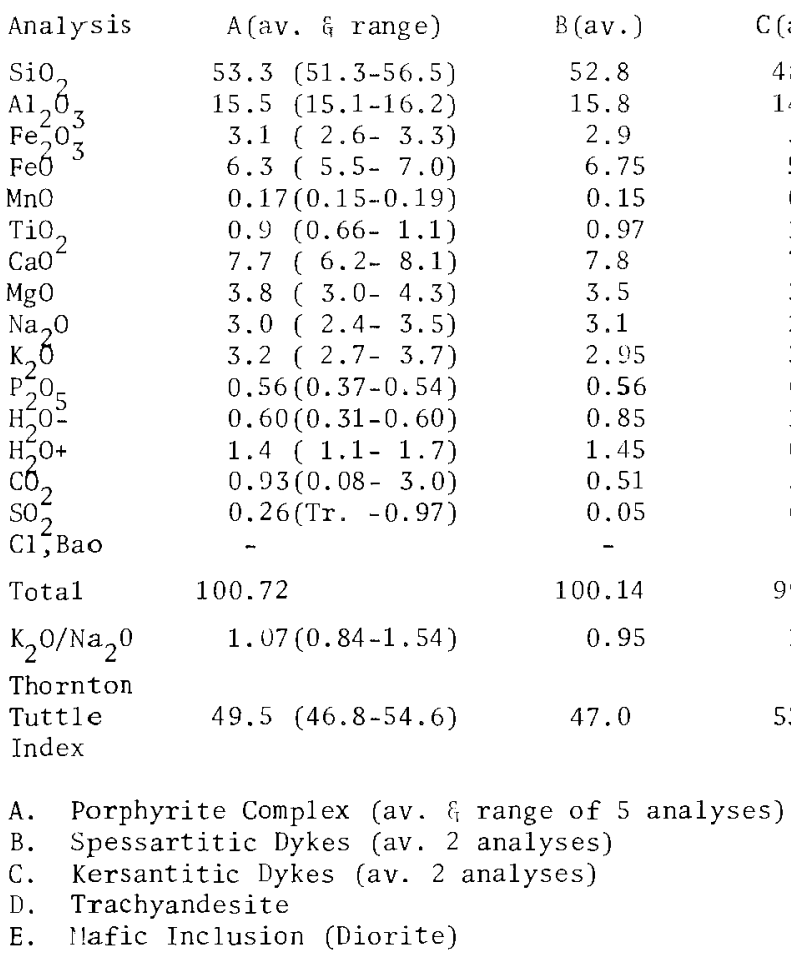

The main intrusion is dominated by darker, medium grained, biotite-rich rocks intimately associated with texturally similar, but pale coloured, fine to coarse phases. Only one case of reaction was noted, where a body of very coarse, pale rock 0.3 by $1 \mathrm{~m}$ across showed a reaction border $3 \mathrm{~cm}$ wide. In places, the darker rocks are cut by dykes of pale rock with banded edges, and quartz (-siderite) and carbonate (-hematite) veins are common. The south side of the intrusion is a complex arrangement of deformed sheets of the normal pale and dark granitic rocks, associated with fine-grained spotty and nodular spinel-bearing phases and pale coarse dykes. Several dykes of the dark rock, including a toumaline-rich variety, extend southwards into deformed breccia and dolomitic sediments. Hitered pale dykes also intrude the dolomitic sediments on the northern side of the body.

In thin sections, most of the rocks are altered to varying degrees and even after sodium cobaltinitrite staining it sometimes proved difficult to distinguish between potassic and sodic feldspars. The rocks may contain up to almost $30 \%$ essential quartz although the majority carry between $10-15 \%$ and rare rocks lack quartz. The darker rocks show the least alteration and contain ragged corroded biotite flakes up to $7 \mathrm{~mm}$ long and making up of $30 \%$ of some specimens. The biotites develop a foliation in a few cases and crystals are sometimes deformed with small kink bands; there may be some alteration to clilorite and actinolite. Actinolite laths are unevenly distributed and are often partly intergrown with sericite and quartz. The feldspars form cloudy, irregular to tabular and stumpy crystals, made pinkish by dusty hematite 
Suite Port Cygnet Syenitic \& Alkaline

Intrusives (Edwards 1947 Tables 1 \& 2 )

West Coast Lamprophyres (Age Uncertain]

\begin{tabular}{|c|c|c|c|c|c|c|c|}
\hline & \\
\hline Analysis & $F\left(a v_{0}\right)$ & $G\left(a v_{.}\right)$ & H(av, \& range) & $I(a v \cdot)$ & $J$ & K & L \\
\hline $\mathrm{SiO}_{2}$ & 62.18 & 61.70 & $55.43(54.20-57.75)$ & 45.94 & 54.6 & 46.16 & 66.4 \\
\hline $\mathrm{A}_{2} \mathrm{O}_{3}$ & 17.85 & 20.00 & $19.58(18.80-20.91)$ & 11.33 & 15.2 & 12.7 & 16.35 \\
\hline $\mathrm{Fe}_{2}^{2} \mathrm{O}_{7}^{3}$ & 1.31 & 1.25 & $3.67(1.71-6.05)$ & 3.93 & 6.3 & 1.58 & 0.98 \\
\hline $\mathrm{Fe} \mathrm{O}^{3}$ & 2.60 & 0.86 & $1.81(0.84-3.73)$ & 5.20 & 6.3 & 9.51 & 2.48 \\
\hline MnO & 0.27 & 0.03 & $0.29(0.12-0.77)$ & 0.24 & $\mathrm{ND}$ & 1.31 & 0.24 \\
\hline $\mathrm{TiO}_{2}$ & 1.05 & 0.08 & $0.28(0.10-0.45)$ & 1.11 & 0.07 & 0.71 & 0.24 \\
\hline $\mathrm{CaO}^{2}$ & 3.85 & 2.30 & $3.92(2.35-5.65)$ & 8.21 & 2.7 & 6.12 & 3.37 \\
\hline $\mathrm{MgO}$ & 0.87 & 0.57 & $0.64(0.40-1.01)$ & 12.08 & 3.3 & 12.79 & 1.45 \\
\hline $\mathrm{Na}_{2} \mathrm{O}$ & 4.12 & 2.52 & $3.74(2.80-4.57)$ & 0.98 & 1.2 & 0.94 & 4.31 \\
\hline $\mathrm{K}_{2} \mathrm{O}$ & 4.34 & 9.44 & $8.45(7.57-9.39)$ & 3.19 & 8.2 & 0.80 & 2.78 \\
\hline $\mathrm{P}_{2}^{2} \mathrm{O}_{5}$ & 0.46 & 0.50 & $0.21(\operatorname{Tr} . \quad-0.50)$ & 0.67 & ND & 0.13 & 0.14 \\
\hline $\mathrm{H}_{2}^{2} \mathrm{O}_{-}^{5}$ & 0.0 & 0.50 & $0.45(0.15-0.85)$ & 1.56 & & & 0.17 \\
\hline $\mathrm{H}_{2}^{2} \mathrm{O}+$ & 0.58 & 0.39 & $0.37(0.11-0.05)$ & 3.14 & ND & 5.61 & 0.96 \\
\hline $\mathrm{CO}_{2}$ & 0.12 & 0.0 & $0.08(0.0-0.38)$ & 2.05 & ND & ]. .93 & 0.04 \\
\hline $\mathrm{SO}_{2}^{2}$ & - & - & $0.25(0.0-1.21)$ & 0.50 & - & - & - \\
\hline $\mathrm{C} 1, \mathrm{BaO}$ & - & - & - & 0.16 & - & - & - \\
\hline Total & 99.60 & 100.14 & 99.17 & 100.29 & - & 100.29 & 99.97 \\
\hline $\mathrm{K}_{2} \mathrm{O} / \mathrm{Na}_{2} \mathrm{O}$ & 1.07 & 3.84 & $2.85(1.67-3.10)$ & 3.26 & 6.83 & 0.85 & 0.65 \\
\hline Thornton & & & & & & & \\
\hline $\begin{array}{l}\text { Tuttle } \\
\text { Index }\end{array}$ & 73.2 & 83.5 & $76.2(72.7-80.2)$ & 28.0 & - & 15.5 & 74.10 \\
\hline
\end{tabular}

F. Syenjtic complex (av. of 2 analyses).

G. Saturated dykes (av. 2 analyses).

H. Unsaturated dykes (av, \& range of 5 analyses).

I. Augite-minette (Queenstown, Solomon 1964).

J. Vogesite (Noddy Creek, Close 1972).

K. Spessartite (Raglan Range, Gee 1963).

L. Acid dyke (Raglan Range, Spry and Banks 1962, Analysis 72, 1). 283) .

inclusions and are commonly sericitized. K-feldspar and zoned sodic plagioclase (most1y $>$ Ab65) occur in variable proportions. Perthitic and blotchy intergrowths are common, but polysynthetic cross-twinning is generally absent. The K-feldspar forms intricate graphic intergrowths with quartz (commonly as overgrowths on large crysta1s). Quartz generally forms less than $15 \%$ of these rocks which grade from quartz-biotite syenites into granites and quartz-monzonites. The main accessories are idioblastic magnetite, common apatite and some pale green spinel within the feldspar; secondary carbonate is common.

The pale associates of the biotitic rocks largely represent strongly altered varieties, in which characteristically biotite is replaced by muscovite, sericite, chlorite and iron oxide, actinolite is replaced with sericite and carbonate and much of the feldspar is replaced by carbonate. Leucocratic rocks, 1acking mica and generally poorer in quartz can also be distinguished. They are composed dominantly of $\mathrm{K}$ feldspar-sodic plagioclase mosaics, in which microline is conspicuous; they are probably later phases and include an aplitic monzonite or diorite with toumaline (schorlite, $\omega$ blackish green, $\varepsilon$ yellowish rose).

The complex intrudes late Precambrian/Lower Cambrian (?) beds, but its precise age is uncertain. It is centred within and shows some petrological similarities to the minettes which may represent a more basic phase. Minette dykes have not been traced into the complex itself, but they are found about $100 \mathrm{~m}$ away where they appear to show a textural transition between the normal lamprophyre and the granitic complex. The granite does not show any close resemblance petrographically 
to the typical Cambrian or Devonian granitic bodies of the state (D.I. Groves and M.J. Rubenach, pers. comm.).

Age of West Coast Lamprophyres

The lamprophyres intrude representatives of all the major Precambrian and

Lower Palaeozoic units in western Tasmania, including:

(i) "Older Precambrian" quartzites and schists at Raglan Range, Gordon Dam and south of Low Rocky Point.

(ii) "Younger Precambrian" (?) quartzites and phyllites at Hibbs Lagoon.

(iii) Late Precambrian or early Cambrian quartzites, dolomites, slates and siltstones at Birthday Bay and Varna Bay.

(iv) Lower Middle Cambrian (?) greywackes, siltstones and cherts on the Gordon River Road near Florentine River.

(v) Lower Middle Cambrian (?) intermediate volcanics at Cypress Creek.

(vi) Lower. Middle Cambrian (?) slates and greywacke at Spero Bay.

(vij.) Middle-Upper Cambrian (?) greywackes and siltstones, as well as gabbro and ultranafic rocks at Noddy Creek.

(viii) Cambrian acid volcanic schists around Queenstown.

(ix) Siluro-Devonian Eldon Group rocks near the Olga River.

(x) Lower Middle Devonian Spero Group quartzites and conglomerates at whitehorse Bay; this gives a lower age limit for at least some of the West Coast 1 amprophyres.

At Noddy Creek, the dykes generally parallel shear planes in the ultramafic rocks and bedding or cleavage in sediments, but one cross-cutting dyke has been traced from sediments into serpentinite (Close 1972); these relationships suggest postMiddle Cambrian emplacement. At Queenstown, the lamprophyres form generally unsheared, occasionally bifurcating dykes that dip $78-85^{\circ} \mathrm{W}$ on north westerly trends and post-date the mineralization, faulting and shearing (Solomon 1964; K.0. Reid pers. comm..); this suggests an Upper Devonian or younger age. Similarly the Raglan Range lamprophyres (Spry 1957, Gee 1963) show related trends discordant with the local foliation and are associated with a major Tabberabberan fault. Intrusions at Clearwater Bay and Gordon Dam are cut or locally sheared by post-Lower Devonian faulting (M.R. Banks, V.E. Thonson and G.T. Roberts, pers. comm.).

Generally the West Coast lamprophyres have been attributed to the post-Tabberabberan granite intrusions (Upper Devonian to Lower Carboniferous; McDougal1 and Leggo 1965), but without firm evidence of an upper age limit. On the other hand, Close (1972) considered the Noddy Creek lamprophyres as late stage differentiates in a period of Cambrian intrusion which started with the ultramafic rocks of the Hibbs belt. He suggested that they may be hypabyssal equivalents of various quartz dolerite, granodiorite and microgranite intrusions in the area and related them to the Darwin Granite, the Elliot Bay adamel1ite (minimum age $407 \mathrm{~m} \cdot \mathrm{y}$; ; ricDougall and Leggo 1965) and a granodiorite $5 \mathrm{~km}$ west of Birchs Inlet.

Close figured a "boudinized lamprophyric dyke cut by veins of carbonate material and surrounded by sheared serpentinite" and in another example showed chloritization and chrysotile vein formation post-dating crystallization of both the lamprophyric dyke and ultramafic host. This would be evidence for Cambrian age and association for the Noddy Creek lamprophyres, only if the shearing and alteration of the ultramafics which affects the dykes can be shown to be Cambrian.

On present evidence, several relationships are possible:

(i) The Noddy Creek lamprophyres are contemporaneous with those which intrude Lower Middle Devonian beds at Whitehorse Bay.

(ii) The Noddy Creek dykes are older than and may have a different origin from some other similar West Coast lamprophyres. However, there is little chemical or petrological evidence to link the lamprophyres with either ultramafic, basic or granitic Cambrian igneous activity.

(iii) Some, or all, of the west Coast lamprophyres and possible link rocks such as 
the Varna Granite are essentially contemporaneous with petrologically similar rocks dated as Upper Mesozoic at King Island, Cape Portiand and Cygnet.

The West Coast minettes show striking petrographic similarities, although there is a strong spread in chenjstry between sone variants (af. augite minette and biotite vogesite analyses, Table 1). This consistency might suggest a single intrusive period, but field relationships are somewhat ambiguous in this regard. The age assigned to some of the "shearing" and chrysotile voining in the Noddy Creek minette is critical here. Whether j.t was associated with upper Cambrian, Tabberabberan or later movenents is arguable and perhaps it was locally associated with tensional emplacement and remobilizing effects of hot volatile lamprophyric nagma or even with post-lamprophyre epeirogenic movement in a sensitive serpentinite host. Recent research indicates that chrysotile vein formation can occur under static condjtions in equilibrium with groundwater near the surface at any time after ultramafic emplacement, (Barnes and O'Neil, 1969; Coleman 1971).

The lamprophyres are presumably far more numerous than yet seen in the poor West Coast exposures and until they can be accurately dated a widespread role in the Upper Mesozoic magmatism cannot be discounted on present evidence. Minor postTabberabberan microporphyritic basic dykes are also known to intrude the folded rocks at Waratah, Pieman River, Rosebery, kenison Bell and Inkerman and Collingwood Rivers (D.I. Groves, R. L. Brathwaite, J.R. Griffiths and author's obs.). However, chemically (D.I. Groves, analysis) and in thin sections these rocks closely match the chilled Mid-Jurassic tholeiite of the State and are probably not related to the lamprophyric activity.

\section{RELATIONSHIPS WITH BASS STRAIT}

Mesozoic igneous rocks are recorded in wells drilled in sediments of the otway, Bass and Gippsland Basins. The majority are basic volcanics and intrusives (mainly basalts and olivine-basalts) that appear mostly within the Jurassic succession. (J.R. Griffiths pers. comm.) and are dated at $153+5 \mathrm{~m} . y$. in the Casterton 1 well (Cundi11 in Parkin et al., 1969). These probably 1 argely represent effusive phases following the Mid-Jurassic tholeijtic injections in Tasmania. (160-167 m.y.; McDougal1 1961), but some more acidic rocks may relate to the Upper Mesozoic intermediate intrusives described herein. Such rocks include granitic dykes noted at several horizons within the Otway Group (Lower Cretaceous) in Hawkesdale 1 Well (Hocking 1970; J.R. Griffiths pers. comm.) and a Mesozoic (?) trachyte (orthoclase porphyry) described in Bass 2 Well (ESSO Exploration Aust. Inc. 1966). Andesitic fragments of unknown source, probably outside Victoria, were reported in the Strze1ecki Group (Upper Jurassic/Lower Cretaceous) sediments of S.E. Victoria (Edwards and Baker 1943; Singleton 1968). In thin sections these 'andesitic' grains appear identical in mineralogy to examples of the Cape Portland appinitic suite (F.L.S. obs.) and are probably derived from this igneous episode.

\section{DISCUSSION}

This survey indicates that igneous activity was a significant feature of the Upper Mesozoic in Tasmania. The Mid-Jurassic tholeiitic floods gave way in Upper Jurassic/Cretaceous time to more sporadic localized intermediate and alkaline intrusjons associated with lamprophyric swarms. The Upper Mesozoic bodies were relatively restricted in size and represent the southern extension of similar intrusive activity in Bass Strait and eastem Australia (e.g. Kemezys 1971; Sutherland 1973a). Volcanism was associated with the Cape Portland centre, at 1east, but at Cygnet-D'Lntrecasteaux Channel there is some suggestion that the intrusives failed to penetrate the Triassic cover. Thus, large areas of Triassic outcrop in Tasmania could conceal further such occurrences and their subterranean presence may be indicated only fortuitously at the surface in possible accidental inclusions in Cainozoic basalts in these areas. 
It is now clear that lamprophyric intrusives exposed in the folded pre-Permian basement of Tasmania, and previously generally ascribed to the Devonian-Carboniferous or earlier intrusive episodes, without conclusive evidence, alternatively could represent the Upper Mesozoic episode. Some similar rocks exist anongst these separate suites and their petrological distinction may be difficult without extremely detailed work. The presence of substantial sulphjde and other mineralization, and the nature and degree of alteration, in such rocks may guide age assignment, but these are not consistently or completely reliable criteria. This problem is hjghlighted by the lamprophyric swarm in western Tasmania. Lintil precise ages of these rocks are established, knowledge of the extent of Upper Mesozoic activity hovers uncertainly between State-wide and more locally sporadic limits. Palaeomagnetic determinations, where suitable, may be the most expedient method of resolution here, in view of the significant differences in Devonian-Lower Carboniferous and Mesozoic Australian pole positions (Brown, Campbell and Crook 1968). However, preliminary tests on a Noddy Creek lamprophyre showed that some of the typical minettes at least are virtually non-magnetic and not susceptible to this method (W.D. Parkinson, pers. comm.).

The Upper Mesozoic activity produced intermediate and alkaline rocks at Cape Portland and Cygnet-D'Entrecasteaux Channel(Table 1). The Cygnet intrusives, with their relatively high potash were included as representatives of the shoshonitic association by Joplin $(1964-71,1965)$. The Cape Portland rocks also show some affinities with the shoshonitic association and chemically approach an intermediate position between absarokite and shoshonite types as defined by Joplin (1968). Their magma seems to represent a more undifferentiated type for derivation of the acidic alkaline Cygnet magma, whose rocks, with higher Thornton-Tuttle Indices, fall largely in the latite and high K-trachyte types of Joplin.

More detailed aspects of the shoshonitic relationship in the Upper Mesozoic of Tasmania in regard to their chemistry and tectonic setting in Eastern Australia are given elsewhere (Sutherland 1973a), but the conclusions from both papers are combined here in the following summary for completeness.

\section{SUMMARY}

1. Upper Mesozoic igneous activity was probably more widespread in Tasmania than previously realized.

2. These rocks are generally potassic and dated types include olivine augite minette on King Island (137 m.y.), K-rich porphyrites, lamprophyres and 'trachyandesites' at Cape Portland, N.E. Tasmania $(103+23 \mathrm{~m} . y$. , Lower Cretaceous?), and banatitic syenite with saturated and under-saturated alkaline derivatives at Cygnet $(98+3 \mathrm{~m} . \mathrm{y}$.$) .$

3. They resemble examples elsewhere in the Upper Mesozoic of Australiā, but their relationships are less obscured by other contemporaneous igneous activity.

4. Their intrusive sequence and major element chemistry suggest a shoshonitic differentiation series.

5. Reconstruction of their tectonic setting, suggests that the magmas evolved under a largely stable continental margin bordering the New Zealand Geosyncline.

6. Since, post-Gondwanaland continental drifting began, the non-orogenic Tasmanian land mass has passed through a general sequence of tholeiitic to olivine-tholeiitic (?) (Mid to Upper Jurassic), shoshonitjc (late Jurassic to Mid-Cretaceous) and basic alkaline to tholeitic (Cainozoic) igneous episodes.

\section{ACKNOWLEDGMENTS}

The authors received considerable assistance with unpublished mapping, specimens, information and constructive criticism from B.H.P. Co. Ltd., K.O. Reid (Mt. Lyell Mining Co. Pty. Ltd.), V.E. Thomson, G.T. Roberts and G.E. Hale (Hydro-E1ectric Commission), H.R. Lanks, M.J. Rubenach, N.C. White, J.R. Griffiths, R.J. Ford, J. L. Cocker, B. Wyatt, W.D. Parkinson (Geology Department, University of Tasmania), D.J. Jennings, B.I. Groves, I.B. Jennings, K.D. Corbett, N. Farmer, A.J. No1dart, G. 
Everard and E. Williams (Tasmania Department of Mines) and R. Webb (Latrobe).

\section{REFERENCES}

Barnes, I. \& O'Neil, J.K., 1969: The Relationship between fluids in Some Fresh Alpine-Type Ultramafics and Possible Modern Serpentinization, Western United States. Buzz. Geol. Soc. Amer., 80, 1947-1960.

Brown, D.A., Campbe11, K.S.W., \& Crook, K.A., 1968: The Geological Evolution of Australia and New Zealand. Pergamon Press.

Buch, L. von, 1814: Einige Bemerkunger uber die geognostiche Constitution von Van Diemens Land. Mag. fur. die Neu Entdeckungen in der Gesammte Naturkunde, 6, $234-240$.

Close, R.J., 1972: The Geology and Economic Potential of the Hibbs Ultramafic Belt in the Noddy Creek Area, S.W. Tasmania. Koyal Melbourne Institute of Technology, Fellowsinip Diploma Thesis, unpub1.

Cocker, J.0., 1971: The St. Helens Pluton Petrology and Structure. Univ. Tasm. B.Se. (Hons) Thesis, unpubl.

Coleman, R.G., 1971: Petrologic and Geophysical Nature of Serpentinites. BuZZ. Geol. Soc. Amer., 82, 887-918.

Edwards, A.B., 1947: Alkali Hybrid Rocks of Port Cygnet. Proc. R. Soc. Vict., $58,81-115$.

¿ Baker, G., 1943: Jurassic arkose in southern Victoria. ibid, 54, 195-228.

ESSO Exploration Australia Inc., 1966: Bass-2-We 22 Completion Report.

Evernden, J.F. and Richards, J.R., 1962: Potassium-argon ages in eastern Australia. J. geol. Soc. Aust., 9, 1-49.

Gee, D.R., 1963: Structure and Petrology of the Raglan Range. BuzZ. geol. Surv. Tasm., 47.

Green, D.H., 1959: Geology of the Beaconsfield District, including the Anderson

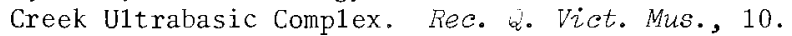

Hi11s, C.L. and Carey, S.W., 1949: Geology and Mineral Industry in Handbook for Tasmania, Aust. Ass. Advanc. Sci. Hobart. , Reid, A.M., Nye, P.B., Keid, H.G.W. G Reid, W.D., 1922: The Coa1 Resources of Tasmania, Tasm. Dept. Mines Miner. Res. 7.

Hocking, J.B., 1970: Petrographic Description of Selected Cores of Igneous Rocks from Shel1's Hawkesdale-1 We11, utway Basin, in Hawkesdale-1-Well Completion Report.

Hogg, E.C., 1901-1902: The Glacial Beds of Little Peppermint Bay, Tasmania. Pap. Proc. R. Soc. Tasm. for 1900-1901. (1902), 136-137.

Jennings, D.J. and Sutherland, F.L., 1969: Geology of the Cape Portland Area with special reference to the Mesozoic (?) Appinitic Rocks. Tech. Rep. Dep. Min. Tasm., 13, 45-82.

Jennings, I.B., Woldart, A.J. G Williams, E., 1967: Geology and Mineral Resources of Tasmania. Bulz. geol. Surv. Tasm., 50 .

Johnston, R.M., 1888: A Systematic Account of the Geology of Tasmania. Govt. Printer, Hobart.

Joplin, G.A., 1964-1971: A Petrogrophy of Australion Igneous Rocks. Angus \& Robertson, Sydney, 1st to 3rd Editions.' 1965: The problem of the potash-rich basaltic rocks. Mineralog. $\mathrm{Mag},, 34,266-275$. $15,275-294$. , 1968: The Shoshonite Association: A Review. J. geol. Soc. Aust.,

Kemezys, K.J., 1971: Mid-Cretaceous Mineralization in South-eastern Australia. Search, 2, 6, 202.

Leaman, D.E. and Naqvi, I.H., 1967: Geology and Geophysics of the Cygnet District. Buzz. geoz. Surv. Tasm., 49.

Longman, M.J., 1961: An Occurrence of Hornblende Picrite in N.E. Tasmania. Tech. Rep. Dep. Min. Tasm., 5, 209-210. Dept. Min. Tasm.

$$
\text { , 1966: Lxplanatory Report. 1-mi Ze geol. Map. Ser. - Launceston. }
$$


l. IcDougall, I., 1961: Jetermination of the Age of a Basic Intrusion by the Potassium-Argon Method. Nature, lond. 190, 1184-1186.

, and Leggo, P.J., 1965: Isotopic Age Determinations on Granitic

Rocks from Tasmania. J. seoz. Soc. Aust., 12, 295-332.

Métais, D. and Chayes, F., 1963: Varieties of Lamprophyre. Ib. Camegie Instn. Wash., 62, 156-157.

Nockolds, S.k., 1954: Average Chemical Composition of some igneous rocks. Bull. geol. Soc. Amer., 65, 1007-1032.

Parkin, L.W. (Ed.) et at, 1969: ilandbook of South Australian Geology. Geol. Surv. South Aust.

Robertson, W. A. and Hastie, 1., 1962: Palaeomagnetic Study of the Cygnet Alkaline Complex. J. geol. Soc. Aust., 8, 259-268.

Scott, B., 1951: The Petrology of the Volcanic Rocks of South-last King Island, Tasmania. Pap. Proc. R. Goc. Tasm. (1950), 113-136.

Skeats, E.W., 1971: On the Age of the Alkali Rocks of Pt. Cygnet. Proc. R. Soo. Vict., 29, 154-164.

Singleton, O.P., 1968: South Gippsland in McAndrew, J., and Marsden, (1.A.H. (Ed.), Regional Guide to Victorian Geology, Geol. Dept. Univ. Melb.

Smith, J.H., 1899: Discovery of Gold at Port Cygnet. Rep. Secr. Mines Tasm. for 1898-99, xiii-xv.

Solomon, 1., 1964: The Spizite-Keratophyre Association of West Tasmania and the Ore Deposits at Mt. Lyez2, Rosebery and Hercules. Univ. Tasm., Ph. U. thesis, unpub 1 .

Spry, A.H., 1957: Precambrian Rocks of Tasmania, part I. Dolerites of the North West Coast; part II. Sit. Mary Area. Pap. Proc. R. Soc. Tasm., 91, 81-93, 95-108. , G Banks, M.R. (Eds), 1962: The Geology of Tasmania. J. geoz. Soc. Aust., 9,2 .

Strzelecki, P.E. de, 1845: Physical Descmiption of New South Wates and Van Dieman's Lond. Longman, Brown, Green \& Longmans, Lond.

Sutherland, F.L., 1971: The Classification, Distribution, Analysis and Sources of Materials in Flaked Stone Implements of Tasmania Aborigines. Rec. Q. Vict. Mus., 42 .

, 1973a: The Shoshonitic Association in the Upper Mesozoic of Tasmania. J. geol. Soc. Aust., 19, 487-496.

, 1973b: The Geological Development of the Southern Shores and Islands of Bass Strait. Proc. R. Soc. Vict., 35, 2, 133-144.

Tasmanian Department of Mines, 1970: Catalogue of the Minerals of Tasmania. Rec. geol. Surv. Tasm., 9 .

Taylor, B.L., 1955: Asbestos in Tasmania. Miner. Resour. Tasm., 9.

Twelvetrees, w.H., 1902: leport on Gold and Coal at Port Cygnet. Rep. Secr. Mines Tasm. for 1901-02, 260-268.

1908: Report on Gold at Port Cygnet and Wheatleys Bay, Huon River. ibid for $1907,33$.

, G Petterd, W.F., 1898: The Igneous Rocks of Tasmania. Trons.

Austrazas. Inst. Win. Engrs., 5, 108.

¿ Petterd, W.F., 1899-1900: On Hauyue Trachyte and Allied Rocks

in the Districts of Port Cygnet and Oyster Cove. Rep. Secr. Min. Tasm., (1898-99), xix-xxvi; Pap. Froc. R. Soc. Tasm. (1898), 3-26.

Walker, K. .., 1957: Geology of the St. Helens-Scamander Area. Pap. Proc. R. Soc. Tasm., 91, 109-114.

Waterhouse, L.L., 1916: Notes on the Geology of King Island. Rep. Secr. Min. Tasm., (1915), 89-93.

Wyatt, B.W., 1971: Palaeomagnetism of Tasmanian Cainozoic Basalts. Univ. Tasm., B.Sc. (Hons) Thesis, unpub1. 